\title{
An Analysis of Pakistani, Japanese, and U.S. Initial Public Offering Performance: Is Ownership Concentration Important?
}

\author{
Zachary Alexander Smith ${ }^{1}$, Hakan Kislal ${ }^{2}$ and Muhammad Zubair Mumtaz ${ }^{3}$
}

\begin{abstract}
This study analyzed the performance of initial public offerings listed on Pakistani, Japanese, and American financial markets conditioned on group-level and founder-level concentration. We found that concentration harmed initial public offering (IPO) performance in Japan but had a positive impact in Pakistan. Looking more specifically at whether ownership concentration leads to positive or negative performance results, it was found that concentration was negatively related to performance in Japan; however, in Pakistan, founder-level concentration seemed to be aligned with positive performance results while group-level concentration to the negative performance results.
\end{abstract}

Keywords: IPO Performance, Ownership Concentration

JEL Classification: G12, G14, G24, G32

\section{Introduction}

Over time, the customs ascribed to a particular region, whether it is a nation or a village or town, have shaped how people interact with each other, how they work, and how the ownership of the businesses that they work in are structured. When we examine the differences between the US style of business organization and other countries, we see a disparity in the ownership structures of the organizations. La Porta, Lopez-de-Silanes, and Shleifer (1999) illustrated that there are significant differences between ownership structures of businesses in 27 countries which included both developed and developing economies. Further, La Porta et al. (1999) explained how shareholder protections in countries can affect and influence how firms are owned and whether the owners exert undue influence over the cash flow rights of the firms that they are associated with. La Porta et al. (1999) found that in their sample of 27 countries that 26 percent of these firm's ownership structure had some type of pyramidal ownership. They drew a clear line between countries that developed their securities' markets based on a common-law and the countries' that did the same based on a civil law system. Further, they found

\footnotetext{
${ }^{1}$ Assistant Professor of Economics and Finance, Saint Leo University, FL, USA.

${ }^{2}$ Professor, Saint Leo University, FL, USA.

${ }^{3}$ Associate Professor of Finance, School of Social Sciences \& Humanities, National University of Sciences \& Technology,

Islamabad.

Corresponding author’s Email: zubair@s3h.nust.edu.pk
} 
that the distinction between common law and civil law origins had significant ramifications for the development and functioning of securities markets and provided a linkage between the development of securities laws, ownership concentration, and valuation. Moreover, that firms with greater protection over minority shareholders experienced a positive relationship between firm valuation and higher cash flow rights by the controlling shareholders.

Berle and Gariner (1991) voiced their concern over the concentration of power that is bestowed on the management team based on a dispersed ownership structure. Smith (1852) illustrated this fear more directly, "The directors of such companies, however, being the managers rather of other people's money than their own, it cannot well be expected that they should watch over it with the same anxious valiance with which the partners in a private copartnery frequently watch over their own" (p. 311). To contend with this potential problem, many firms in countries outside of the US seem to have a greater concentration in their ownership structures, which potentially leads them to exert undue influence over cash flow rights. This paper is motivated by the sentiment provided in La Porta et al. (1999), Bearle et al. (1991), and Smith (1852), which examine the differences in corporate control, organizational performance, and organizational structure in different countries and their influence on the development of capital markets.

In particular, we aimed to compare and contrast the two developed nations (i.e. US and Japan) that have highly developed stock markets in order to determine how business structure affects the stock market performance of firms that have gone public from 2013 to 2015 and introduce a third, the emerging market economy, Pakistan, as an attempt to draw some comparisons between the first two nations and draw some implications for how investors experience IPO investments in the three markets. In doing so, we intend to provide a linkage between stock market performance and ownership control. Moreover, we highlight a comparison of how two countries in Asia (i.e., Pakistan and Japan), one whose legal structure was built upon a common law framework (Pakistan) and the other that was built upon a civil law framework (Japan) seem to view ownership concentration through very different lenses as indicated by post-IPO performance based on group- and founderlevel concentrations.

In this paper, we have presented some interesting findings. First, we illustrate that when examining the one-year market returns after the issuance of IPOs, the not-so-concentrated Japanese firms were able to time their IPOs better than the firms with more concentration. Moreover, the post-issuance market's performance was higher for Japanese IPOs that have less concentrated ownership. 
There was no relationship between post-IPO market performance and concentration in the US or the Pakistani sample.

Second, we showed that when Japanese firms have groups of concentrated owners that these IPO firms produce statistically and economically significant lower post-IPO raw returns when compared against firms that do not have concentrated ownership. Similar to the previous statement on the US IPOs, there is a weak statistically significant relationship between concentration at the first level of shareholding and raw IPO performance in the US and Pakistan. This seems to suggest that firms with concentrated ownership structures time their IPOs better, ensuring the best interest of a controlling shareholder.

Finally, we illustrated how when Japanese firms have groups of concentrated owners, their Cumulative Abnormal Returns (CARs) are statistically and economically less than the IPOs that have minimal concentration in their ownership structure. In the cases of Pakistani and the US IPOs, we found evidence of the opposite relationship, which suggests that concentration might provide a positive signal to the marketplace. We also identified weak statistical evidence of this in the US IPO markets and a strong statistical evidence of this in the Pakistani IPO market. In order to further emphasize these general relationships, we ran less restrictive tests of proportions to determine whether, after conditioning on shareholder concentration, we identify evidence of abnormal performance in IPOs one-year after the issuance. We found that ownership concentration significantly and negatively affects the one-year performance of the Pakistani and Japanese IPOs, but not the US IPOs.

In the final test, we compared the performance of firms with very high levels of ownership concentration to firms with very low levels of concentration using the Herfindahl-Hirschman Index (HHI) and found that, in terms of market-adjusted performance, Pakistani IPOs perform better when there is a high level of ownership concentration contrary to the Japanese IPOs; whereas, the US IPOs had insignificant market-adjusted returns. These results, collectively, illustrate that concentration, whether it comes in the form of business groups or individual concentration of ownership, generates statistically and economically significant underperformance for the Japanese IPOs while the Pakistani IPO performance provides a stark contrast to the relationship that was generated between concentration and IPO performance in the Japanese sample.

The rest of the study is structured as follows. Section 2 provides an overview of ownership concentration, Section 3 discusses the data and 
methodology, Section 4 examines the empirical results and Section 5 concludes the study.

\section{Literature Review}

Agency theory is used as almost a ubiquitous term to describe the relationship between the principals and agents in a firm's organizational structure. Bearle et al. (1991) illustrated that as owners delegate responsibilities to their employees the cost to monitor their employees' performance increases as they are incentivized to engage in non-value maximizing activities such as prerequisite taking and empire building. Jensen and Meckling (1976) claimed that owners could potentially reduce the conflict between principals and agents by increasing the insiders' stake in the company up to a point in which they would have total control. Prendergast (2017) highlighted modern agency theory and provided a general account of how the conflict between principals and agents should be addressed by varying compensation with performance when performance information is available. This is very similar to the sentiment reached in Jensen et al. (1976) indicating that the most appropriate way to incentivize an agent to work in the best interest of the firm is through provision of ownership stakes. Prendergast (2017) indicates that the traditional model does not hold because of the incentive alignment issues that employees face. In this study we examine whether and if ownership concentration is related to performance; thus, we are taking a more in-depth look at the relationship between ownership concentration and performance within the context of agency theory.

Many studies find evidence of a positive relationship between ownership concentration and firm performance. For example, Bruton, Filatotchev, Chahine, and Wright (2010) find evidence that falls in line with the general idea that concentration of ownership improves company performance in the United Kingdom and France. Similarly, Iwasaki and Mizobata (2020) in a meta-analysis that examined the performance of emerging market economies in Central and Eastern Europe including the former Soviet Union found a positive relationship between firm performance and ownership concentration. Moreover, Gedajlovic and Shapiro (2002) found evidence of a positive relationship between ownership concentration and firm performance from 1986 to 1991 in Japan using a sample of 334 companies. Further, Ullah (2017) examined the relationship between ownership concentration and firm performance for 1362 firms listed on the TSE (Tokyo Stock Exchange) from 1991 to 2009 and found that there was a positive relationship between insider's share of ownership and firm performance. Additionally, Yasser and Al Mamun (2017) found that there was a positive 
relationship between firm performance and ownership concentration from 2009 to 2013 using a sample of 95 Pakistani firms. Gugler, Mueller, and Yurtoglu (2008) used a sample of 3,614 US companies from 1989 through 1997 and found a positive relationship between insider ownership and performance. This review of studies illustrates how pervasive the evidence relating performance to ownership concentration is.

Transiting to our aim in this particular study, we intend to look more intimately at the relationship between ownership concentration and firm performance in a developing and a developed country in Asia and use US evidence as a comparison. The reason for this is that in some Asian economies and companies that have businesses across Continental Europe ownership concentration seems to be more prevalent compared to US companies. Specifically, in Asian markets, there have been numerous studies outlining the importance of the ownership structures referred to as the keiretsu in Japan, the chaebol in Korea, the jituan qiye in China, or the trading houses in India. The question that this paper explores is what effect, if any, do these ownership structures have on their company's performance? This study compares the performance of Japanese, US, and Pakistani IPOs based on ownership concentration (at issuance of the IPO shares).

By comparing these three nations this study will be able to offer insight into the perception that shareholders in economies that have pyramidal ownership structures possess about these ownership structures and contrast those against countries that have more dispersed ownership structures. Further, we will explore the relationship between concentration and performance across different levels of development (i.e. developed versus emerging), fundamental rules of laws (i.e. common versus civil law heritage), and cultures. There is a lot to learn about how ownership concentration affects firm performance in these different nations. This study attempts to shed light on and build a conversation around ownership concentration and its effect on IPO performance over the initial year of seasoning. To accomplish this task, we took a country that is located in the west, the US, that has a developed market whose securities laws framework was grounded in the common law tradition, and two countries that are located in the east, one that is developed, Japan, whose securities laws framework were grounded in the civil law tradition and the other, Pakistan, that is developing whose securities law's framework were grounded in the common law tradition. Note, that traditionally the common law framework has been claimed to have better protections for minority shareholders when compared against civil law legal origins (La Porta et al., 2002). 
Throughout the literature, numerous studies have attempted to highlight the problems associated with concentrated ownership structures. Specifically, how owners can, sometimes, expropriate undue control or cash flow rights if they have the right ownership structure and the regulatory regime does not offer strong protection for shareholder rights (Albuquerque \& Schroth, 2015; Claessens \& Djankov, 1999; Darmadi \& Gunawan, 2013; Dhillion \& Rossetto, 2015; Earle, Kucsera, Telegdy, 2005; Heugens, van Essen, \& van Oosterhout, 1999; Keister, 1998; Wang \& Shailer, 2013; Wang et al, 2015). La Porta, Lopez-de-Silanes, Shleifer, and Vishny (2002) explained that the concentration of control rights in firms, as opposed to cash flow rights, provides owners with the opportunity to expropriate benefits in an efficient and seemingly disproportionate manner to their actual cash flow rights. In La Porta et al. (2002), they build a model of how an entrepreneur might attempt to expropriate an undue share of control rights over the firm by establishing cross-shareholding relationships to exert control, divert cash flows, or tunnel a firm's profits. The costs associated with stealing in the La Porta et al. (2002) model is greater in a nation with more protective legal regimes; so, the likelihood of excess appropriation decreases.

There are a number of studies that relate the idea of ownership control to company performance across many economies, both emerging and developed (Claessens \& Djankov, 1999; Earle, Kucsera, \& Telegdy, 2005; Heugens, van Essen, \& van Oosterhout, 2009; Wang \& Shailer, 2013). For example, Claessens and Djankov (1999) found from 1992 to 1997 that as the concentration of ownership increased in Czech firms the profitability and labor productivity increased. Earle, Kucsera, and Telegdy (2005) found in a study of the Budapest Stock Exchange where the size of the largest shareholder block was positively associated with profitability and efficiency; however, after controlling for the size of the first block-holder, the concentration effect wears off and turns insignificant. Heugens, van Essen, and van Oosterhout (2009) conducted a meta-analysis of Asian firms' performance and found a small but positive association between performance and concentration.

Wang and Shailer (2013) conducted a meta-analysis of ownership concentration and firm performance in the emerging markets and found that ownership concentration had a negative relationship with firm performance across countries after considering the population differences, researchers' modeling choices, and that endogeneity caused issues when researchers attempted to analyze and evaluate the relationship between ownership concentration and performance. However, the data from the Japanese studies were not included in their metaanalysis and they seemed to be more interested in examining the relationship 
between ownership concentration and emerging market economies, which generally have weaker institutional structures (Wang et al., 2013).

According to Wang et al. (2013), the theoretical basis for obtaining a positive relationship between ownership concentration and performance is based upon theories related to "interest alignment, ownership as a substitute for weak legal and institutional environments, and ownership signaling of commitment to bailout and not to expropriate a firm" (p. 2). Likewise, Wang et al. (2013) provided the theoretical basis for a negative relationship between ownership concentration and performance as being related to the "controlling shareholder agency problem, the cost of capital hypothesis, and negative impact on other corporate governance mechanisms" (p. 2). Similarly, Javid and Iqbal (2008) contend in their study of 60 Pakistani firms that ownership concentration is an endogenous substitute for poor shareholder protection and has a significant impact on the firm performance. In another study, Javid and Malik (2016) studied the performance of 72 Pakistani IPOs from 2001 to 2015 period and documented that initial returns are inversely related to ownership concentration. This evidence was contrary to signaling theory which showed that concentrated ownership signaled the issuers to evaluate the quality of the firm thereby resulting in underpricing. Related to our conversation about ownership control is a field of inquiry focused on examining the relationship between the concentrated block ownership of securities. In general, large concentrated positions create inefficiencies in the marketplace which have been shown to affect the pricing of securities. For example, Barclay and Holderness (1989) explored the pricing of 63 block trades of greater than 5\% of a listed company between 1978 and 1982 and found that the trades often executed at a premium of, on average, 20\%. Barclay et al. (1989) conclude that this block trade premium reflects the private benefits associated with voting power within the firm. This premium is paid to allow the block shareholder to extract pecuniary or nonpecuniary benefits from the firm (Barclay et al., 1989, p. 374). Among other things, Albuquerque and Schroth (2015) explored the relationship between the valuation and the illiquidity of the shares of controlling blocks using the US data. In their model, there were two different sets of investors and they were referred to as the control block owners and the dispersed shareholders (Albuquerque et al., 2015). They found that the marketability or the block discount was on average $30 \%$ but had a median value of $12 \%$ and determined that this discount was explained by two effects, which were the probability of the firm experiencing a liquidity shock and the potential effect of a fire sale of that firm.

Transitioning from block ownership of shares to block ownership of initial public offerings (IPOs), Dhillo and Rossetto (2014) presented a model that 
predicted that as the size of the block for the median shareholder of a firm decreased the firm value and risk associated with the firm increased. They continued to cite various research studies indicating that support the idea that the effects of block holders were typically positive. Further, they attempted to generalize their model to IPO performance and indicated that underpricing can be higher when the initial owner wanted to avoid additional trading blocks and claim that underpricing increases as the size of the trading block increases. Finally, the researchers indicated that underpricing occurred if the shared control of multiple block shareholders was greater and they explained that minority shareholders could extract an illiquidity premium from the block holders as the size of that block increased.

All of the aforementioned studies indicate that concentration and the existence of concentrated trading blocs within firms affect not only the bloc participants but the market value of the companies that they own and the valuation that the non-bloc participants should place on the firm. A different form of control is an ownership wedge, a divergence between cash flow and ownership rights, and Wang, Cao, Liu, Tang, and Tian (2015) found, in a study of non-SOE (State Owned Enterprises) in China, that firms that have a control-ownership wedge underperform non-control-ownership wedge firms over 1, 2, and 3-year performance windows from 2002 to 2010. In another study, Darmadi and Gunawan (2013) suggested, after evaluating 101 Indonesian IPOs from 2003 to 2011, that ownership concentration had an insignificant effect on very short-term performance but conjectured that there would be a positive relationship between underpricing and ownership concentration because the owners of the firm would want to incentivize broad ownership and oversubscribed issues so that they would not have very large blocks of shareholders.

Research on how ownership concentration affects the performance of IPOs is relatively sparse across all markets and this study adds to the literature by providing a comparison of how ownership concentration in different shareholder levels affects the short-run (i.e., one-year) performance of IPOs in two developed nations and a third emerging nation.

\section{Data and Methodology}

\subsection{Data}

For this study, we collected data on the IPOs for Japanese and US firms from 2013 and 2015. Due to the small size of the Pakistani capital market, we considered a sample of IPOs issued from 2004 to 2015. The data on the date of 
issuance and the percentage of ownership for the top five shareholders was obtained from the Japan Exchange Group for the Japanese IPOs and form 424B4 filed with the Securities Exchange Commission (SEC) for the US firms. With regard to the percentage of ownership for the top five shareholders for Pakistani IPOs was gathered from the IPO prospectus. Note, the specific type of ownership that we extracted from these offering documents is direct ownership by level of shareholding at the time of the issuance of the unseasoned shares. Additionally, because the level of concentration is pulled directly from the offering documents, we are interested in analyzing the relationship between the initial level of concentration for the IPO, which is a decision that the founder makes as they decide how much of their firm's control they want to give up, and IPO performance.

We also obtained performance data for the Nikkei 225 Index and the S\&P 500 Index from Yahoo! Finance and collected weekly annual performance data from the IPOs went public on one of the market division in the Tokyo Pro Market and the US IPOs from Google Finance. For measuring the performance of IPOs, we extracted the market returns from the database of the Pakistan Stock Exchange (PSX). The initial data set of IPOs that went public during this time frame for the Japanese IPOs was 334 companies and 36 companies did not have enough performance data or data could not be obtained and for the United States IPOs we had 656; and 91 companies were either partnerships or missing data; therefore, we used 298 Japanese IPOs and 565 US IPOs to carry out the analysis. For Pakistan, we used 84 IPOs listed during the period between 2004 and 2015.

\subsection{Methodology}

Numerous studies on the relationship between ownership concentration and firm performance or valuation have been carried out using the event study methodology and the Cumulative Abnormal Return (CAR) method to identify abnormal performance. As an example, Barclay and Holderness (1989), in a study of concentrated ownership, collected data on firms whose shareholders engaged in block trading of at least $5 \%$ of the value of equity firms trading on the NYSE or AMEX and determined that block trades typically occur at a premium over the postblock trade price. To determine whether the block trades produced a positive or negative performance event, the researchers apply the event study methodology and use the CAR estimation technique.

Further, Albuquerque and Schroth (2015) use percentage ownership of 35\% to $90 \%$ as a proxy for block shareholding within the event study framework and applied the CAR methodology to examine the effect of liquidity shocks on block shareholders' wealth. Moreover, Wang, Cao, Liu, Tang, and Tian (2015) traced the 
cash flow rights associated with an investor's stake in a particular firm by examining the pass-through ownership associated with investors having ownership stakes in a particular firm through their investments in different companies. Although the approach that they use to differentiate between control rights (i.e. ownership) and cash flow rights is novel, they rely on the CAR method within the event study framework to determine if ownership concentration affected long-term IPO performance.

This study makes adjustments to the way that ownership concentration is measured in an attempt to gain additional insight into the relationship between ownership concentration and performance. In the ensuing paragraphs, we outline how we calculated abnormal returns and how we proxied for ownership concentration within the event study methodological framework.

\subsubsection{Abnormal Returns}

To identify whether returns are normal or abnormal, we first needed a method to aggregate the individual returns and then a method to compare the aggregate returns against a model of the market. Traditionally, this type of analysis is carried out using some type of market model (Lo, 2005; Markowitz, 1952), asset pricing model (Fama \& French, 1993; 2015; Ross, 1976; Sharpe, 1964), and a method to aggregate returns in longer-term studies (Barber \& Lyon, 1997). In our case, we operate under the initial assumption that there is no abnormal performance; therefore, the market's returns in a given period should be equivalent to the IPO's returns and vice versa. This is a simplification of more complex models, but it is useful because it provides us with a relatively simple way to compare the magnitude of abnormal performance within our concentration of ownership levels; therefore, the model of abnormal performance is as follows:

$$
A R_{i, t}=R_{i, t}-R_{m, t}
$$

\subsubsection{Cumulative Abnormal Returns}

Furthermore, we aggregate all of these individual returns into a Cumulative Abnormal Return (CAR) estimate using the following procedure (similar to Barber \& Lyon, 1997 in Equation 2) and the sample standard deviation as follows in Equation 3; moreover, the test statistics to test whether there is a statistically significant difference between the two samples is provided below (i.e., Equation 4):

$$
\overline{C A R}=\frac{1}{n} \sum A R_{i, t}
$$




$$
\begin{gathered}
\overline{s_{C A R}}=\sqrt{\frac{\sum\left(A R_{i, t}-0\right)^{2}}{n-1}} \\
t=\frac{\overline{C A R_{A}}-\overline{C A R_{B}}}{\sqrt{\frac{\overline{s_{C A R_{A}}^{2}}}{N_{A}}+\overline{\frac{s_{C A R_{B}}^{2}}{N_{B}}}}}
\end{gathered}
$$

The $\overline{C A R}$ that we generate is an estimate of the average abnormal returns experienced by investors holding the IPOs for one-year as compared to the market's return. On average, the Pakistani IPOs generated $20.55 \%$ returns over the first year of listing with a standard deviation of $79.67 \%$ and the market's return were $20.71 \%$ with a standard deviation of $25.73 \%$, the Japanese IPOs produced $27.13 \%$ returns over the first year of seasoning with a standard deviation of $111.25 \%$ and the matched market's return were $14.46 \%$ with a standard deviation of $24.91 \%$, and the US IPOs obtained $24.90 \%$ performance over the first year with a standard deviation of $77.01 \%$ and the matched market's return were $8.8 \%$ with a standard deviation of $7.76 \%$.

We then employed the following algorithm: If firm $i$ 's $1^{\text {st }}$ shareholder has less or equal to $10 \%$ ownership of the firm, then they are a member of Cohort $A$. If firm $i$ 's $1^{\text {st }}$ shareholder has greater than $10 \%$ ownership of the firm, then they are a member of Cohort $B$. We continued this procedure moving to the $2^{\text {nd }}, 3^{\text {rd }}$, and $4^{\text {th }}$ ownership levels of the firm maintaining the $10 \%$ ownership threshold. This strategy allowed us to segment the raw returns, market returns, and market-adjusted returns based upon the concentration at each level of ownership.

We contend that by employing this technique, we will be able to generate some understanding of the relationship between shareholder concentration at each level of shareholding and performance. By segmenting the population of IPOs in this manner, we believe that it allowed us to proxy for differences in the performance of IPOs that are controlled by affiliated investment groups and those that have individual founders. This distinction is important because the literature related to the business groups (i.e., keiretsu in Japan, the chaebol in Korea, the jituan qiye in China, or the trading houses in India) suggests that these groups can exert disproportionate influence over the cash flow rights of a firm than their ownership rights would otherwise entitle them. By applying this statistical technique, we believe that as we move from the first to the fourth level of shareholding, an increase in the statistical significance between our tests illustrates 
evidence that investors believe that business groups may exert unfair control over cash flow rights as group-level ownership concentration increases.

\subsubsection{Test of Proportions}

To provide an absolute test of performance, we, first, segmented the sample population of IPOs into two distinct groups, which were identified as concentrated or not concentrated in terms of their ownership. We defined the concentration of $10 \%$ or greater in each shareholder position as concentrated. This $10 \%$ level was selected based on the US Securities \& Exchange definition or classification of the level of ownership in a company that would lead an individual to be identified as an 'insider' where individuals are assumed to have some unfair informational advantage over the rest of the public and were subjected to more stringent rules with regards to trading their shares. We segment the sample population as concentrated or non-concentrated for each of the shareholder positions (i.e. from the most concentrated shareholder level to the second most concentrated, to the third most concentrated, and so on) and generated the raw returns, CARs, and market returns for each paired sample based on the sorting criteria and a comparison of the two classes (i.e. concentrated and not concentrated).

The methodology used to determine the statistical significance was as follows and this hypothesis test was examined by comparing whether there was ownership concentration at the first, second, third, and fourth level of the shareholding of $10 \%$ ownership or more and performance. Next, we categorized a positive performance result as a success (i.e. $Y_{1}$ would be coded a success if the concentrated firm had a positive performance event and $\mathrm{Y}_{2}$ would be coded as a success if the nonconcentrated firm had a positive performance event and $\mathrm{n}_{1}$ would be the sample size of the sample with concentrated ownership and $\mathrm{n}_{2}$ would be the sample size of the sample with nonconcentrated ownership). Finally, we ran the following hypothesis test to determine if there was a statistically significant difference between the estimates obtained in this analysis based on the ownership concentration of the firm:

$$
\begin{gathered}
H_{0}: p_{\text {concentrated }}-p_{\text {not concentrated }}=0 \\
H_{a}: p_{\text {concentrated }}-p_{\text {not concentrated }} \neq 0 \\
Z=\frac{\left(\hat{p}_{1}-\hat{p}_{2}\right)-0}{\sqrt{\hat{p}(1-\hat{p})\left(\frac{1}{n_{1}}+\frac{1}{n_{2}}\right)}}
\end{gathered}
$$

In which $\hat{p}=\frac{Y_{1}+Y_{2}}{n_{1}+n_{2}}$ is the number of successes in the two combined samples. 
The test of proportions metric provides us with a way to identify less obvious trends in the data and is simply another way to group the data to determine if there are trends that we may not have identified using other statistical techniques. Asking whether ownership concentration, at a particular level of shareholding, led to a positive or negative performance result over the ensuing year of seasoning provides us with an indication of how ownership concentration might affect performance across these three regions. We believed that by differentiating between concentration at the first and fourth level of shareholding we will be able to provide some indication of what type of ownership concentration is influencing the performance results (i.e. individual/owner or group level concentration).

\subsubsection{Test of Proportions and the Herfindahl-Hirschman Index (HHI)}

To continue our analysis, we wanted to segment firms that have ownership concentration that is considered extremely concentrated, and firms that have minimal ownership concentration. To accomplish this, we applied the HerfindahlHirschman Index (HHI) to categorize firms as highly concentrated firms and firms that have low levels of concentration. According to Hirschey (2009), the HHI "is a popular measure of competitor size inequality that reflects size differences between large and small firms" (p. 529), which is defined as follows according to Hirschey (2009):

$$
H H I=\sum_{i=1}^{n}\left(\frac{\text { Firm Sales }_{i}}{\text { Industry Sales }} * 100\right)^{2}
$$

In this paper, we adopted the HHI to provide us with a proxy of firm concentration that allowed us to segment the sample population into highly concentrated firms and firms that had relatively low concentration levels. Our adjusted $\mathrm{HHI}$ is defined as follows:

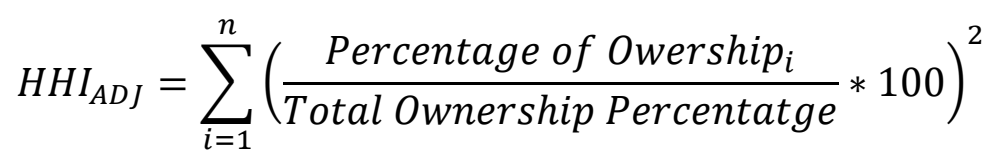

This adjusted form of the HHI, which is identified as $\mathrm{HHI}_{\mathrm{ADJ}}$ will allow us to segment the sample population based on the level of ownership concentration. 10,000 is a maximum level for the HHI and would illustrate that $100 \%$ of the firm is held by the first shareholder [e.g. $(1 * 100)^{2}$ ]; however, if the first and second shareholder each owned $50 \%$ of the firm the $\mathrm{HHI}_{\mathrm{ADJ}}$ would equate to 5,000 and so on. According to the U.S. Department of Justice and the Federal Trade Commission (2010) based on agency experience, levels for the HHI that are greater than 2,500 
indicate high concentration levels, and less than 1,500 indicate low levels of concentration and this is the standard that we adopted for our $\mathrm{HHI}_{\mathrm{ADJ}}$ measure. Using the $\mathrm{HHI}_{\mathrm{ADJ}}$ measure as a sorting mechanism, we grouped the entire sample into cohorts that had high levels of concentration (i.e. they had an $\mathrm{HHI}_{\mathrm{ADJ}}$ of greater than 2,500) and low levels of concentration (i.e. they had an $\mathrm{HHI}_{\mathrm{ADJ}}$ of less than $1,500)$.

Next, we sorted the high and low level of concentration samples into groups of positive performances, which we categorized as successes, and negative performances. The proportion of positive performances in the high $\mathrm{HHI}_{\mathrm{ADJ}}$ group was then compared against the proportion of the positive performance in the low $\mathrm{HHI}_{\mathrm{ADJ}}$ group and we ran the following statistical test:

$$
\begin{aligned}
& H_{0}: p_{H H I_{>2500}}^{+}-p_{H H I_{<1500}}^{+}=0 \\
& H_{a}: p_{H H I_{>2500}}^{+}-p_{H H I_{<1500}}^{+} \neq 0 \\
& Z=\frac{\left(p_{H H I_{>2500}}^{+}-p_{H H I_{<1500}}^{+}\right)-0}{\sqrt{\hat{p}(1-\hat{p})\left(\frac{1}{n_{1}}+\frac{1}{n_{2}}\right)}}
\end{aligned}
$$

In which $\hat{p}=\frac{Y_{1}+Y_{2}}{n_{1}+n_{2}}$ is the number of successes in the two combined samples (i.e. $Y_{1}$ is the number of observations that were greater than zero in the sample of companies that had an $\mathrm{HHI}_{\mathrm{ADJ}}$ of greater than 2,500 and $\mathrm{Y}_{2}$ is the number of observations that were greater than zero in the sample of companies that had an $\mathrm{HHI}_{\mathrm{ADJ}}$ of less than 1,500; moreover, $\mathrm{n}_{1}$ and $\mathrm{n}_{2}$ are the number of companies in the sample of companies that have an $\mathrm{HHI}_{\mathrm{ADJ}}$ of greater than 2,500 and the number of companies in the sample of companies that have an $\mathrm{HHI}_{\mathrm{ADJ}}$ of less than 1,500).

Given that we are segmenting the IPOs performance results across the different regions into cohorts of very concentrated firms and unconcentrated firms, this segmentation provided us with a clear understanding of the differences in the performances associated with very concentrated firms (i.e. founder concentrated firms) and firms that are not concentrated. This last test will help us to differentiate between firms that have group-level concentration and firms that have ownership that is concentrated at the founder level. To obtain an HHI of 2,500, the level of concentration of ownership at the first level of shareholding is at least $25 \%$, assuming that all other levels (i.e., two through four) are 25\%; however, it is more likely indication of concentration of ownership at that first or first and second levels of shareholding and not representative of group concentration. 


\section{Empirical Results}

This section is broken into three distinct subsections. First, we will provide a comparison of the raw performance of IPOs, the performance of the market when the IPOs were issued, and the market-adjusted performance of the IPOs issued on the US, Japanese, and Pakistani markets. Next, we will compare positive and negative events conditioned on whether the ownership concentration is high or low and examine raw performances, market matched performances and marketadjusted performance associated with concentration. Finally, we break the samples up into high and low concentrated IPOs in the US, Japanese, and Pakistani Markets and employed a two-subsample $t$-test to compare the raw returns, paired market returns, and the market adjusted returns based on ownership concentration.

\subsubsection{Raw Returns Obtained by the Market One-Year Following IPO Conditioned on Concentration}

The results presented in Table 1 provide evidence that in Japan as firm ownership becomes more and more concentrated across the $1^{\text {st }}, 2^{\text {nd }}, 3^{\text {rd }}$, and $4^{\text {th }}$ shareholder positions, the difference in the one-year post-IPO performance declines subsequentially. However, there is no relationship between concentrated ownership at the different levels of shareholding for the Pakistani and US IPOs and subsequent market performance.

As illustrated in Table 1 (Panel B) for the Japanese firms, when we compared the firms that are not concentrated against the firms that are concentrated, the market's returns associated with decisions to go public for firms that do not have concentrated ownership structures perform better than the firms that have concentrated ownership structures. Also, when we compare the concentration of the groups, the statistical significance associated with the different levels of concentration decreases as we move from evaluating concentration at the first shareholder position to the concentration at the fourth shareholder position. What the results indicate is that as the level of concentration of the ownership structure for Japanese IPOs decreases the market returns after the IPO is issued increases; this seems to suggest that as ownership becomes less concentrated, Japanese firms seem to time their IPOs better. 
Table 1: Raw Returns Obtained by the Market One-Year Following IPO Conditioned on Concentration

\begin{tabular}{|c|c|c|c|c|c|c|c|c|}
\hline \multirow{2}{*}{$\begin{array}{l}\text { Statistic } \\
\text { Concentration }\end{array}$} & \multicolumn{2}{|c|}{ 1st Shareholder } & \multicolumn{2}{|c|}{ 2nd Shareholder } & \multicolumn{2}{|c|}{ 3rd Shareholder } & \multicolumn{2}{|c|}{ 4th Shareholder } \\
\hline & $\begin{array}{c}<\text { or }=\text { to } \\
10 \%\end{array}$ & $>10 \%$ & $\begin{array}{c}<\text { or }=\text { to } \\
10 \%\end{array}$ & $>10 \%$ & $\begin{array}{c}<\text { or }=\text { to } \\
10 \%\end{array}$ & $>10 \%$ & $\begin{array}{c}<\text { or }=\text { to } \\
10 \%\end{array}$ & $>10 \%$ \\
\hline \multicolumn{9}{|l|}{ Panel A: Pakistan } \\
\hline Average & $13.85 \%$ & $16.45 \%$ & $16.10 \%$ & $16.30 \%$ & $17.47 \%$ & $13.63 \%$ & $17.14 \%$ & $11.30 \%$ \\
\hline Standard Deviation & $40.77 \%$ & $27.90 \%$ & $28.41 \%$ & $29.27 \%$ & $31.95 \%$ & $21.56 \%$ & $30.03 \%$ & $22.83 \%$ \\
\hline Sample Size & 7 & 77 & 29 & 55 & 57 & 27 & 71 & 13 \\
\hline$t$ value & \multicolumn{2}{|c|}{-0.17} & \multicolumn{2}{|c|}{-0.03} & \multicolumn{2}{|c|}{0.61} & \multicolumn{2}{|c|}{0.80} \\
\hline \multicolumn{9}{|l|}{ Panel B: Japan } \\
\hline Average & $31.02 \%$ & $12.68 \%$ & $18.26 \%$ & $11.55 \%$ & $15.40 \%$ & $13.03 \%$ & $15.30 \%$ & $12.60 \%$ \\
\hline Standard Deviation & $26.15 \%$ & $24.15 \%$ & $25.89 \%$ & $23.73 \%$ & $24.70 \%$ & $26.52 \%$ & $25.33 \%$ & $19.62 \%$ \\
\hline Sample Size & 29 & 269 & 139 & 155 & 233 & 57 & 274 & 11 \\
\hline t value & \multicolumn{2}{|c|}{$3.62 * * *$} & \multicolumn{2}{|c|}{$2.31^{* *}$} & \multicolumn{2}{|c|}{0.61} & \multicolumn{2}{|c|}{0.44} \\
\hline \multicolumn{9}{|c|}{ Panel C: United States } \\
\hline Average & $8.60 \%$ & $8.81 \%$ & $9.18 \%$ & $8.50 \%$ & $9.01 \%$ & $8.26 \%$ & $8.78 \%$ & $8.96 \%$ \\
\hline Standard Deviation & $7.65 \%$ & $7.78 \%$ & $7.57 \%$ & $7.90 \%$ & $7.79 \%$ & $7.69 \%$ & $7.84 \%$ & $6.96 \%$ \\
\hline Sample Size & 44 & 521 & 244 & 321 & 405 & 160 & 512 & 53 \\
\hline t value & \multicolumn{2}{|c|}{-0.18} & \multicolumn{2}{|c|}{1.03} & \multicolumn{2}{|c|}{1.05} & \multicolumn{2}{|c|}{-0.18} \\
\hline
\end{tabular}

Note: The results above illustrate the difference in the performance of the market's raw returns following a new issue when the $i$ th shareholder of the IPO firm had less than or equal to $10 \%$ ownership in the company, which fall in Cohort A, as compared against the $i$ th shareholder having greater than $10 \%$ ownership of the company, which falls in Cohort B. ***, **, $\& *$ indicate statistical significance at $.01, .05, \& .10$ levels.

Source: Authors' calculation

\subsubsection{Raw Returns Obtained by IPOs One-Year Following IPO Conditioned on Concentration}

In this section, we evaluated the raw one-year returns of the IPOs and further examined the effect of concentration on these IPOs. The results presented in Table 2, Panel B (for the Japanese IPOs) are interesting because they indicate that as firm ownership becomes more concentrated, the firms that are concentrated generate lower absolute returns as compared to the firms that have less concentrated ownership. More specifically, as we increased the level that we evaluated shareholder concentration (i.e., from the $1^{\text {st }}$ to the $2^{\text {nd }}$ to the $3^{\text {rd }}$ to the $4^{\text {th }}$ ) the difference in the raw returns obtained by the Japanese IPOs that had concentrated ownership and non-concentrated ownership diverged and the raw performance of Japanese IPOs that were not concentrated is better than IPOs that were concentrated. Although the differences between the performance of the concentrated and non-concentrated Japanese IPOs at the first and second 
shareholding level were statistically insignificant the raw differences in performance between the two groups was approximately equal to or greater than $20 \%$. Contrarily, we generate weak statistical evidence that concentration seems to be positively related to the one-year post-issuance performance of IPOs issued in Pakistan and the US; however, it is not as clear as the relationship between concentration in the different levels of shareholding and the IPOs performance as was presented in the Japanese IPO dataset. We will revisit this finding in later sections.

Table 2: Raw Returns Obtained by IPOs One-Year Following the IPO Conditioned on Concentration

\begin{tabular}{|c|c|c|c|c|c|c|c|c|}
\hline \multirow{2}{*}{$\frac{\text { Statistic }}{\text { Concentration }}$} & \multicolumn{2}{|c|}{ 1st Shareholder } & \multicolumn{2}{|c|}{ 2nd Shareholder } & \multicolumn{2}{|c|}{ 3rd Shareholder } & \multicolumn{2}{|c|}{ 4th Shareholder } \\
\hline & $=$ to $10 \%$ & $>10 \%$ & $<$ or $=$ to $10 \%$ & $>10 \%$ & $<$ or $=$ to $10 \%$ & $>10 \%$ & $<$ or $=$ to $10 \%$ & $>10 \%$ \\
\hline \multicolumn{9}{|l|}{ Panel A: Pakistan } \\
\hline Average & -50.97 & $3.77 \%$ & $-11.88 \%$ & $5.05 \%$ & $-9.81 \%$ & $18.23 \%$ & $-1.77 \%$ & $4.53 \%$ \\
\hline Standard Deviation & $69.74 \%$ & $61.41 \%$ & $61.94 \%$ & $62.07 \%$ & $60.57 \%$ & $64.94 \%$ & $64.05 \%$ & $50.37 \%$ \\
\hline Sample Size & 7 & 77 & 29 & 55 & 57 & 27 & 71 & 13 \\
\hline$t$ value & \multicolumn{2}{|c|}{$-2.01 *$} & \multicolumn{2}{|c|}{-1.19} & \multicolumn{2}{|c|}{$-1.89 *$} & \multicolumn{2}{|c|}{-0.40} \\
\hline \multicolumn{9}{|l|}{ Panel B: Japan } \\
\hline Average & $45.16 \%$ & $25.19 \%$ & $36.67 \%$ & $-12.75 \%$ & $33.91 \%$ & $3.91 \%$ & $29.43 \%$ & $-32.84 \%$ \\
\hline Standard Deviation & $83.71 \%$ & $113.77 \%$ & $107.13 \%$ & $115.65 \%$ & $114.51 \%$ & $100.77 \%$ & $110.30 \%$ & $43.23 \%$ \\
\hline Sample Size & 29 & 269 & 139 & 155 & 233 & 57 & 274 & 11 \\
\hline$t$ value & \multicolumn{2}{|c|}{1.17} & \multicolumn{2}{|c|}{1.30} & \multicolumn{2}{|c|}{$1.96^{* *}$} & \multicolumn{2}{|c|}{$4.25 * * *$} \\
\hline \multicolumn{9}{|c|}{ Panel C: United States } \\
\hline Average & $11.64 \%$ & $26.02 \%$ & $21.68 \%$ & $27.34 \%$ & $21.75 \%$ & $32.87 \%$ & $24.73 \%$ & $26.55 \%$ \\
\hline Standard Deviation & $54.51 \%$ & $70.17 \%$ & $64.00 \%$ & $85.60 \%$ & $73.50 \%$ & $84.96 \%$ & $78.41 \%$ & $62.44 \%$ \\
\hline Sample Size & 44 & 521 & 244 & 321 & 405 & 160 & 512 & 53 \\
\hline t value & \multicolumn{2}{|c|}{$-1.61^{\wedge}$} & \multicolumn{2}{|c|}{-0.90} & \multicolumn{2}{|c|}{-1.46} & \multicolumn{2}{|c|}{-0.20} \\
\hline
\end{tabular}

Note: The results above illustrate the difference in the performance of the IPO's raw returns following a new issue when the $i$ th shareholder of the IPO firm had less than or equal to $10 \%$ ownership in the company, which fall in Cohort A, as compared against the $i$ th shareholder having greater than $10 \%$ ownership of the company, which falls in Cohort B. ***, **, *, and ${ }^{\wedge}$ indicate statistical significance at $.01, .05, .10$, and .15 levels.

Source: Authors' calculation.

\subsubsection{CAR Obtained by the IPOs One-Year Following IPO Conditioned on Concentration}

In the third analysis of this section, we examined whether concentration affects the one-year CARs obtained by the IPOs in our sample. In Table 3, we 
compare the results of the CARs obtained as we allowed ownership concentration to increase among IPO firms.

In Panel B of Table 3 (focusing on the Japanese IPOs), as we increased the shareholder position level of concentration we found that the non-concentrated firms gradually generated higher and higher levels of outperformance when compared to the concentrated firms and that the difference in the CARs changed from insignificant to significant at the $1 \%$ level as we increased the shareholder position level of concentration. Similar to the findings in the last section, we generated weak statistical evidence that concentration seems to be positively related to the one-year CARs of IPOs issued in Pakistan and the US; however, again, it is not as clear as the relationship between concentration in the different levels of shareholding and IPO performance that was presented in the Japanese IPO dataset.

Table 3: CARs Obtained by the IPO One-Year Following IPO Conditioned on Concentration

\begin{tabular}{|c|c|c|c|c|c|c|c|c|}
\hline \multirow{2}{*}{$\begin{array}{l}\text { Statistic } \\
\text { Concentratio } \\
\mathrm{n}\end{array}$} & \multicolumn{2}{|c|}{ 1st Shareholder } & \multicolumn{2}{|c|}{ 2nd Shareholder } & \multicolumn{2}{|c|}{ 3rd Shareholder } & \multicolumn{2}{|c|}{ 4th Shareholder } \\
\hline & $\begin{array}{c}<\text { or }=\text { to } \\
10 \%\end{array}$ & $\begin{array}{c}> \\
10 \% \\
\end{array}$ & $\begin{array}{c}<\text { or }=\text { to } \\
10 \%\end{array}$ & $\begin{array}{c}> \\
10 \% \\
\end{array}$ & $<$ or $=$ to $10 \%$ & $\begin{array}{c}> \\
10 \% \\
\end{array}$ & $<$ or $=$ to $10 \%$ & $\begin{array}{c}> \\
10 \% \\
\end{array}$ \\
\hline \multicolumn{9}{|l|}{ Panel A: Pakistan } \\
\hline Average & $-64.52 \%$ & $-12.68 \%$ & $-27.97 \%$ & $-11.26 \%$ & $27.28 \%$ & $4.61 \%$ & $18.91 \%$ & $-6.77 \%$ \\
\hline Standard Deviation & $71.68 \%$ & $60.94 \%$ & $56.83 \%$ & $64.10 \%$ & $60.20 \%$ & $64.82 \%$ & $63.87 \%$ & $49.37 \%$ \\
\hline Sample Size & 7 & 77 & 29 & 55 & 57 & 27 & 71 & 13 \\
\hline t value & \multicolumn{2}{|c|}{$-1.85^{*}$} & \multicolumn{2}{|c|}{-1.22} & \multicolumn{2}{|c|}{$-2.15^{* *}$} & -0.78 & \\
\hline \multicolumn{9}{|l|}{ Panel B: Japan } \\
\hline Average & $14.14 \%$ & $12.51 \%$ & $18.41 \%$ & $8.25 \%$ & $18.51 \%$ & $-9.12 \%$ & $14.12 \%$ & $-45.44 \%$ \\
\hline Standard Deviation & $70.65 \%$ & $108.74 \%$ & $98.93 \%$ & $\begin{array}{c}112.41 \\
\%\end{array}$ & $\begin{array}{c}108.71 \\
\%\end{array}$ & $96.36 \%$ & $\begin{array}{c}104.33 \\
\%\end{array}$ & $46.29 \%$ \\
\hline Sample Size & 29 & 269 & 139 & 155 & 233 & 57 & 274 & 11 \\
\hline t value & \multicolumn{2}{|r|}{0.11} & \multicolumn{2}{|c|}{0.82} & \multicolumn{2}{|c|}{$1.89^{*}$} & \multicolumn{2}{|c|}{$3.89 * * *$} \\
\hline \multicolumn{9}{|l|}{ Panel C: United States } \\
\hline Average & $3.04 \%$ & $17.20 \%$ & $12.49 \%$ & $18.84 \%$ & $12.73 \%$ & $24.61 \%$ & $15.94 \%$ & $17.58 \%$ \\
\hline Standard Deviation & $55.06 \%$ & $77.38 \%$ & $62.98 \%$ & $84.45 \%$ & $72.66 \%$ & $83.28 \%$ & $77.41 \%$ & $60.41 \%$ \\
\hline Sample Size & 44 & 521 & 244 & 321 & 405 & 160 & 512 & 53 \\
\hline t value & \multicolumn{2}{|c|}{$-1.58^{\wedge}$} & \multicolumn{2}{|c|}{-1.02} & \multicolumn{2}{|c|}{$-1.58^{\wedge}$} & \multicolumn{2}{|c|}{-0.18} \\
\hline
\end{tabular}

Note: The results above illustrate the difference in the CARs following a new issue when the ith shareholder of the IPO firm had less than or equal to $10 \%$ ownership in the company, which fall in Cohort A, as compared against the ith shareholder having greater than $10 \%$ ownership of the company, which falls in Cohort B. ***, **, *, and ${ }^{\wedge}$ indicate statistical significance at $.01, .05, .10$, and .15 levels.

Source: Authors' calculations. 


\subsubsection{Summary and Discussion of Results}

According to Gugler, Mueller, and Yurtoglu (2008), the structure of distributed, but group-level, shareholding in Japan has been shown to lead to firmlevel underperformance. Further, they indicate that increasing concentration in US firms is typically related to increases in stock performance. Moreover, that increases in ownership concentration in the US are positively related to wealth effects and offset managerial entrenchment. Contrarily, when focusing on the Asian firms in their sample (i.e., Japan, Korea, and Taiwan) they note that firms from these countries perform differently when compared against the other European firms that grounded their legal systems based on the civil law traditions, thus they assumed that Asian culture may influence firm performance and the relationship between ownership concentration and performance. Recent evidence in Pakistan relating the performance of firms to ownership concentration seems to point to evidence that ownership concentration minimizes management entrenchment and leads to shareholder wealth maximization (Khan \& Nouman, 2021; Rehan \& Javaid, 2019; Waheed \& Malik; Yasser \& Mamun, 2017) similar to what was found in the US sample that Gugler et al. (2008) analyzed. Therefore, we do not believe that there are generalizable differences between the European and Asian corporate governance structures that are based on a continental divide which appropriately explain the difference in the relationship between ownership concentration and performance; however, we do believe that the development of country-specific legal frameworks and customs influence this relationship.

\subsubsection{Tests of Proportions}

In Table 4, we present similar evidence of the distinction of the relationship between ownership concentration and post-IPO performance when comparing the Japanese IPOs and US and Pakistani IPOs; however, these tests of proportions allow us to take a different look at the data using an alternative technique. The question that we are now asking is whether there is a relationship between ownership concentration and one-year post-issuance IPO performance and positive or negative market, IPO returns, and CARs. The results of this analysis, presented in Table 4, help us to parse through the differences in the type of IPO concentration.

In the US IPO data, we do not have any distinct trends, but in the Japanese and Pakistani data, we begin to highlight some interesting findings. For the Japanese IPOs, it seems as though, somewhat consistently across the different tests, that as concentration increases this increase has a negative effect on the post-issuance IPO performance. We posit that this has something to do with the prevalence of business groups in Japan, the history associated with these business groups, and the abuse of 
their collective influence over the cash flow rights for a firm. Interestingly, we identify some evidence of this in our results for the Pakistani IPOs in Panel 4, which seems to suggest that as the 1st, 2nd, 3rd, and 4th shareholding levels become concentrated above the $10 \%$ level, there is a strong negative and statistically significant relationship between this type of group-level shareholding and one-year post-issuance IPO performance. Contrarily, for the Pakistani IPOs, it seems as though concentration at the first level of shareholding could be perceived positively because the results indicate that these types of firms outperform the nonconcentrated IPOs and this result was statistically significant.

Table 4: Test of Proportion for Pakistani, Japanese, and U.S. IPOs

\begin{tabular}{|c|c|c|c|c|c|c|c|c|c|}
\hline & \multicolumn{9}{|c|}{ Panel 1: 1st Shareholder Concentration } \\
\hline & \multicolumn{3}{|c|}{ Pakistani IPOs } & \multicolumn{3}{|c|}{ Japanese IPOs } & \multicolumn{3}{|c|}{ United States IPOs } \\
\hline & $>10 \%$ & $<=10 \%$ & $z$ test & $>10 \%$ & $<=10 \%$ & $z$ test & $>10 \%$ & $<=10 \%$ & $z$ test \\
\hline Raw & $60 \%$ & $0 \%$ & $3.08 * * *$ & $46 \%$ & $69 \%$ & $-2.38 * *$ & $58 \%$ & $50 \%$ & 1.05 \\
\hline Market & $26 \%$ & $27 \%$ & -0.07 & $71 \%$ & $90 \%$ & $-2.15^{* *}$ & $80 \%$ & $84 \%$ & -0.59 \\
\hline CAR & $47 \%$ & $0 \%$ & $2.44 * *$ & $41 \%$ & $52 \%$ & -1.16 & $51 \%$ & $45 \%$ & 0.69 \\
\hline Count & 77 & 7 & & 269 & 29 & & 521 & 44 & \\
\hline \multicolumn{10}{|c|}{ Panel 2: 2nd Shareholder Concentration } \\
\hline Raw & $56 \%$ & $73 \%$ & $-1.57^{\wedge}$ & $41 \%$ & $57 \%$ & $\begin{array}{c}- \\
2.77 * * *\end{array}$ & $57 \%$ & $58 \%$ & -0.11 \\
\hline Market & $26 \%$ & $25 \%$ & 0.12 & $69 \%$ & $78 \%$ & $-1.82 *$ & $78 \%$ & $84 \%$ & $-1.74 *$ \\
\hline CAR & $50 \%$ & $39 \%$ & 1.04 & $36 \%$ & $48 \%$ & $-2.09 * *$ & $51 \%$ & $50 \%$ & 0.35 \\
\hline Count & 55 & 29 & & 155 & 139 & & 321 & 244 & \\
\hline \multicolumn{10}{|c|}{ Panel 3: 3rd Shareholder Concentration } \\
\hline Raw & $58 \%$ & $62 \%$ & -0.48 & $32 \%$ & $52 \%$ & $2.81^{-} * * *$ & $60 \%$ & $56 \%$ & 0.85 \\
\hline Market & $21 \%$ & $28 \%$ & -1.03 & $68 \%$ & $75 \%$ & -1.07 & $82 \%$ & $80 \%$ & 0.44 \\
\hline CAR & $48 \%$ & $46 \%$ & 0.23 & $26 \%$ & $45 \%$ & $-2.63 * * *$ & $56 \%$ & $48 \%$ & $1.55^{\wedge}$ \\
\hline Count & 27 & 57 & & 57 & 233 & & 160 & 405 & \\
\hline \multicolumn{10}{|c|}{ Panel 4: 4th Shareholder Concentration } \\
\hline Raw & $32 \%$ & $68 \%$ & $-4.23 * * *$ & $9 \%$ & $50 \%$ & $-2.66 * * *$ & $62 \%$ & $57 \%$ & 0.73 \\
\hline Market & $23 \%$ & $26 \%$ & -0.56 & $82 \%$ & $74 \%$ & 0.60 & $81 \%$ & $81 \%$ & 0.08 \\
\hline CAR & $23 \%$ & $54 \%$ & $-3.85 * * *$ & $9 \%$ & $43 \%$ & $-2.24 * *$ & $57 \%$ & $50 \%$ & 0.94 \\
\hline Count & 13 & 71 & & 11 & 274 & & 53 & 512 & \\
\hline
\end{tabular}

Note: In this series of test we compare whether the level of shareholder concentration is related to the raw one-year IPO performance, whether the raw market return associated with the issuance of new IPO shares has a relationship with concentration, and whether there is evidence of a relationship between the level of concentration and one-year marketadjusted performance associated with IPOs. This analysis was carried out on IPOs that were issued from 2013 to 2015 on U.S. and Japanese Exchanges. $* * *, * *, *$, and ${ }^{\wedge}$ indicate statistical significance at $.01, .05, .10$, and .15 levels. Source: Authors' calculation.

The results presented in Table 4, attempt to look more specifically at the differences between founder-level concentration as it relates to IPO performance 
and group-level concentration. Again, there is a significant contrast between the performance of Japanese and Pakistani IPOs. In the case of Pakistan, IPOs that have significant levels of founder concentration outperform, but IPOs that have grouplevel concentration underperform. Shaikh, Fei, Shaique, and Nazir (2019) claim that control-enhancing mechanisms, such as pyramid ownership, allow controlling shareholders to expropriate smaller shareholders. In their study, found evidence of manipulation of accrual-based earnings and real earnings management within firms that had this type of ownership structure. Hence, what we found could be evidence that firms operating under these pyramidal ownership structures are not acting in the shareholders' best interest; whereas, founder-concentration helps prevent managerial entrenchment and maximizes shareholder wealth.

Japanese IPOs seem to consistently have a negative relationship between ownership concentration and IPO performance; whereas, the US sample has no substantiating evidence of a negative relationship between concentration and IPO performance; however, there is weak evidence of a positive relationship between ownership concentration and IPO performance. In Japan, almost all forms of concentrated ownership (i.e., founder and group) seem to affect both the timing of IPOs and their overall performance. Ullah (2017) claims that in Japan there is an unwinding of the control imposed through group-level shareholding. Further, there is a positive relationship between the transfer of ownership from stable investors (i.e., financial institutions and non-financial corporations) that practice group-level shareholding (this typically shields managers from external pressures and the threat of takeovers) to more active investors that provide better monitoring of the firm's managers. This unwinding and transfer of ultimate ownership in a company to investors outside of the traditional keiretsu framework, even in the presence of concentration, should provide opportunities to reduce managerial entrenchment and align their interests to maximize the shareholder wealth.

\subsubsection{Test of Proportions Using the Herfindahl-Hirschman Index (HHI)}

In Table 5, we analyzed whether firms that have less concentrated ownership structures are more likely to experience a positive performance event when they issue their shares on Pakistani, Japanese, and US IPO markets. We found that the Japanese IPO experience is very different from the experience in the US and Pakistani IPO markets. In the aggregate, when we examined the raw and market performance of Japanese IPOs, the firms that had a more disbursed ownership had more positive performance events when compared to firms that had significant ownership concentration. When we evaluated the performance of the firms that 
issued shares on the US and Pakistani equity markets during this time, we found the opposite effect.

Table 5: Test of Proportions - A Comparison of High and Low Ownership Concentration Firms

\begin{tabular}{|c|c|c|c|c|c|c|}
\hline \multicolumn{7}{|c|}{ Panel 1: Pakistani IPOs } \\
\hline & \multicolumn{3}{|c|}{ Low Concentration } & \multicolumn{3}{|c|}{ High Concentration } \\
\hline & $\begin{array}{c}\text { Raw } \\
\text { Return }\end{array}$ & $\begin{array}{c}\text { Market } \\
\text { Performa } \\
\text { nce }\end{array}$ & $\begin{array}{l}\text { Market Adjusted } \\
\text { Performance }\end{array}$ & Raw Return & $\begin{array}{c}\text { Market } \\
\text { Performance }\end{array}$ & $\begin{array}{c}\text { Market } \\
\text { Adjusted } \\
\text { Performance }\end{array}$ \\
\hline $\begin{array}{l}\text { Positive } \\
\text { Outcomes }\end{array}$ & 10 & 32 & 9 & 18 & 26 & 18 \\
\hline Total Outcomes & 37 & 37 & 37 & 35 & 35 & 35 \\
\hline $\begin{array}{l}\text { Proportion } \\
\text { (Positive) }\end{array}$ & $27.02 \%$ & $86.49 \%$ & $24.32 \%$ & $51.42 \%$ & $74.29 \%$ & $51.42 \%$ \\
\hline$t$ Stat & $-1.71 *$ & -0.33 & $-2.10 * *$ & & & \\
\hline \multicolumn{7}{|c|}{ Panel 2: Japanese IPOs } \\
\hline $\begin{array}{l}\text { Positive } \\
\text { Outcomes }\end{array}$ & 80 & 113 & 68 & 29 & 53 & 31 \\
\hline Total Outcomes & 143 & 143 & 143 & 84 & 84 & 84 \\
\hline $\begin{array}{l}\text { Proportion } \\
\text { (Positive) }\end{array}$ & $55.94 \%$ & $79.02 \%$ & $47.55 \%$ & $34.52 \%$ & $63.10 \%$ & $36.90 \%$ \\
\hline$t$ Stat & $3.18^{* * *}$ & $2.61 * * *$ & $1.56^{\wedge}$ & & & \\
\hline \multicolumn{7}{|c|}{ Panel 3: U.S. IPOs } \\
\hline $\begin{array}{l}\text { Positive } \\
\text { Outcomes }\end{array}$ & 173 & 140 & 230 & 108 & 133 & 105 \\
\hline Total Outcomes & 331 & 331 & 331 & 159 & 159 & 159 \\
\hline $\begin{array}{l}\text { Proportion } \\
\text { (Positive) }\end{array}$ & $52.27 \%$ & $42.30 \%$ & $69.49 \%$ & $67.83 \%$ & $83.65 \%$ & $66.04 \%$ \\
\hline$t$ Stat & $-3.28 * * *$ & $-8.63 * * *$ & 0.76 & & & \\
\hline
\end{tabular}

Note: In this series of tests, we compare whether the level of shareholder concentration is related to the raw one-year IPO performance, whether the raw market return associated with the issuance of new IPO shares has a relationship with concentration, and whether there is evidence of a relationship between the level of concentration and one-year marketadjusted performance associated with IPOs using the Herfindahl-Hirschman Index (HHI) as the sorting mechanism. This analysis was carried out on IPOs that were issued from 2013 to 2015 on U.S. and Japanese Exchanges. ***, **, *, and $\wedge$ indicate statistical significance at $.01, .05, .10$, and .15 levels.

Source: Authors' calculation.

Although the results for the CARs in the US IPO cohort were statistically insignificant, the CARs for the Japanese and Pakistani IPOs were statistically significant and produced opposite signs. Moreover, the results for the Japanese IPOs seem to support the general findings and conclusions reached throughout the paper, which were that concentration, in Japan, typically has a negative effect on post-issuance IPO performance. Contrarily, in the Pakistani cohort, we see that significant amounts of concentration, which we contend would be more likely to be associated with founder/owner concentration has a positive relationship with the 
one-year post-issuance IPO performance. The results of this statistical test help us to refine our understanding of how concentration might affect post-issuance IPO performance and distinguish between the effects associated with group-level concentration and significant levels of concentration in the first and second level of shareholding.

As illustrated in previous sections, both the magnitude of concentration and type of concentration has an impact on the timing and performance of IPOs in our sample; however, the results presented for the US sample is less convincing. The differences between Japanese and the Pakistani IPO performance for the high- and low-concentration firms show a clear distinction between these two countries, which indicates that the differences in the relationship between ownership concentration and performance is more 'country-specific' then it is a continent-bycontinent issue (Gugler et al., 2008). Nagata and Nguyen (2017), in their study of disclosure policy in the Japanese market, indicate that concentrated ownership is not associated with better disclosures and they indicate that these concentrated stakes are likely strategic as such the motivations of these concentrated owners are different from active shareholders. It seems as though in the US and Pakistani markets that ownership concentration is used as a monitoring device and a means to control the threat of managerial opportunism (Waheed \& Malik, 2019) and reduce agency problems (Khan \& Nouman, 2017); whereas, in the Japanese IPO market, ownership concentration is still used to extract benefits that are not primarily focused on maximizing shareholder wealth.

\section{Conclusion}

This paper provides performance-based statistically significant evidence which illustrates that concentration, in terms of corporate ownership, affects postissuance IPO performance over a one-year time-horizon in Japan differently than it affects IPO performance in the US and Pakistan. We conjecture that the keiretsu framework and the emphasis on stakeholder value maximization over shareholder maximization in Japan provides a reasonable explanation of why the performance of IPOs in Japan are markedly different from the performance of IPOs in the US and Pakistan. However, when we add the results that were generated across all rounds of the analysis in Pakistan, we see that significant group-level concentration is also negatively related to the one-year post-issuance performance of IPOs, but only at extreme cases of group-level concentration; furthermore, in Pakistan, concentration is not always seen as a bad thing and, at times, Pakistani investors, based on the performance results presented in this paper, seem to see concentration as a positive signal (i.e. founder/owner) as long as that concentration does not trend 
towards the extreme group level concentration. This evidence indicates that, except for extreme levels of group-level concentration, in Pakistan and the US, the use of concentrated ownership seems to provide an appropriate deterrent against managerial entrenchment and aids in maximizing shareholder wealth. In the case of Japan, there could be an unwinding of the control imposed by group-level shareholding (as indicated in Ullah, 2017), but this process of transferring ownership from stable owners to owners that are truly focused on maximizing shareholder wealth is not yet complete and there is still significant evidence of a negative relationship between all types of concentration and IPO performance in the Japanese market for IPOs.

There are a few limitations to this study, we will identify two of our primary limitations. First, when collecting data to study the differences in the performances of IPOs based on ownership concentration across these regions, the Pakistani sample during the 2013 to 2015 was very small compared to the Japanese and US samples, which were 298 and 565 IPOs, respectively. Therefore, we used a sample time horizon lasting from 2004 to 2015 for the Pakistani sample, which provided us with 84 observations. Second, there is evidence that some firms may be more likely to allow concentrated owners to exert excess power over the managers of their firms and the even cash flow rights within the firm. The discussion provided in the literature review highlighted the fact that different regulatory regimes, cultures, and ownership structures have an effect on firm performance and that certain firms (whether they are controlled through a series of cross-shareholding relationships, pyramidal ownership, or other types of concentrated ownership) are more likely to allow large shareholders to obtain influence in excess of what their ownership rights would entitle them. We did not identify a clear way to distinguish these types of firms from firms that are focused specifically on shareholder wealth maximization and this has the potential to lead to potential bias in our results. 


\section{References}

Albuquerque, R., \& Schroth, E. (2015). The value of control and the costs of illiquidity. The Journal of Finance, 70(4), 1405-1455.

Baek, J. S., Kang, J. K., \& Lee, I. (2006). Business groups and tunneling: Evidence from private securities offerings by Korean chaebols. The Journal of Finance, 61(5), 2415-2449.

Barber, B. M., \& Lyon, J. D. (1997). Detecting long-run abnormal stock returns: The empirical power and specification of test statistics. Journal of Financial Economics, 43(3), 341-372.

Barclay, M. J., \& Holderness, C. G. (1989). Private benefits from control of public corporations. Journal of Financial Economics, 25(2), 371-395.

Berle, A. A., \& Means, G. G. C. (1991). The modern corporation and private property (2nd Edition). New York, Routledge, Transaction Publishers.

Bruton, G. D., Filatotchev, I., Chahine, S., \& Wright, M. (2010). Governance, ownership structure, and performance of IPO firms: The impact of different types of private equity investors and institutional environments. Strategic Management Journal, 31(5), 491-509.

Buck, T., \& Tull, M. (2000). Anglo-American contributions to Japanese and German corporate governance after World War Two. Business History, 42(2), 119-140.

Claessens, S., \& Djankov, S. (1999). Ownership concentration and corporate performance in the Czech Republic. Journal of Comparative Economics, 27(3), 498-513.

Darmadi, S., \& Gunawan, R. (2013). Underpricing, board structure, and ownership. Managerial Finance, 39(2), 181-200.

Dhillon, A., \& Rossetto, S. (2015). Ownership structure, voting, and risk. The Review of Financial Studies, 28(2), 521-560.

Earle, J. S., Kucsera, C., \& Telegdy, Á. (2005). Ownership concentration and corporate performance on the Budapest stock exchange: Do too many cooks spoil the goulash. Corporate Governance: An International Review, 13(2), 254-264.

Fama, E. F., \& French, K. R. (1993). Common risk factors in the returns on stocks and bonds. Journal of Financial Economics, 33, 3-56. 
Fama, E. F., \& French, K. R. (2015). A five factor asset pricing model. Journal of Financial Economics, 116(1), 1-22.

Gugler, K., Mueller, D. C., \& Yurtoglu, B. B. (2008). Insider ownership, ownership concentration and investment performance: An international comparison. Journal of Corporate Finance, 14(5), 688-705.

Heugens, P. P., Van Essen, M., \& van Oosterhout, J. H. (2009). Meta analyzing ownership concentration and firm performance in Asia: Towards a more fine grained understanding. Asia Pacific Journal of Management, 26(3), 481-512.

Hirschey, M. (2009). Fundamentals of managerial economics (9th edition). Mason, $\mathrm{OH}$, South Western Cengage Learning.

Hu, Y., \& Izumida, S. (2008). Ownership concentration and corporate performance: A causal analysis with Japanese panel data. Corporate Governance: An International Review, 16(4), 342-358.

Iwasaki, I., \& Mizobata, S. (2020). Ownership concentration and firm performance in European emerging economies: A meta analysis. Emerging Markets Finance and Trade, 56(1), 32-67.

Javid, A. Y., \& Iqbal, R. (2008). Ownership concentration, corporate governance, and firm performance: Evidence from Pakistan. The Pakistan Development Review, 47(4), 643-659.

Javid, A. Y., \& Malik, H. (2016). Performance and capital structure of IPOs in Pakistan from 2000 to 2015. Financial Innovation, 2(14), 1-19.

Jensen, M. C., \& Meckling, W. H. (1976). Theory of the firm: Managerial behavior, agency costs and ownership structure. Journal of Financial Economics, 3(4), 305-360.

Keister, L. A. (1998). Engineering growth: Business group structure and firm performance in China's transition economy. The American Journal of Sociology, 104(2), 404-440.

Khan, F., \& Nouman, M. (2017). Does ownership structure affect firm's performance? Empirical evidence from Pakistan. Pakistan Business Review, 19(1), 1-23.

Kitagawa, T. (1960). Some Reflections on the Corporate Theory, Including a Japanese Perspective. Duke Law Journal, 4, 535-556. 
La Porta, R., Lopez-de-Silanes, F., \& Shleifer, A. (1999). Corporate ownership around the world. The Journal of Finance, 54(2), 471-517.

La Porta, R., Lopez-de-Silanes, F., Shleifer, A., \& Vishny, R. (2002). Investor protection and corporate valuation. The Journal of Finance, 57(3), 11471170 .

Licht, A. N., Goldschmidt, C., \& Schwartz, S. H. (2005). Culture, law, and corporate governance. International Review of Law and Economics, 25(2), 229-255.

Markowitz. (1952). Portfolio selection. The Journal of Finance, 7, 77-91.

Nagata, K., \& Nguyen, P. (2017). Ownership structure and disclosure quality: Evidence from management forecasts revisions in Japan. Journal of Accounting and Public Policy, 36(6), 451-467.

Prendergast, C. (2017). Agency issues. Journal of Political Economy, 125(6), 1878-1884.

Rajan, R. G., \& Zingales, L. (2003). The great reversals: The politics of financial development in the twentieth century. Journal of Financial Economics, 69(1), 5-50.

Rehan, A., \& Javaid, A. Y. (2019). How concentrated ownership affects the growth of firms in pakistan. Journal of Business and Economics, 11(2), 125-141.

Ross. (1976). The arbitrage theory of capital asset pricing. Journal of Economic Theory, 13, 341-360.

Shaikh, R., Fei, G., Shaique, M., \& Nazir, M. (2019). Control enhancing mechanisms and earnings management: Empirical evidence from Pakistan. Journal of Risk and Financial Management, 12(130), 1-23.

Sharpe, W. F. (1964). Capital asset prices: A theory of market equilibrium under conditions of risk. The Journal of Finance, 19(3), 425-442.

Shishido, Z. (2000). Japanese corporate governance. The Delaware Journal of Corporate Law, 25(2), 189-233.

Shishido, Z. (2001). Reform in Japanese corporate law and corporate governance: Current changes in historical perspective. The American Journal of Comparative Law, 49(4), 653-677.

Smith, A. (1852). Wealth of Nations: An Inquiry into the nature and causes of the wealth of nations. London, T, Nelson. 
U.S. Department of Justice and the Federal Trade Commission (2010). Horizontal merger guidelines, Available at: https://www.justice.gov/sites/default/files/atr/legacy/2010/08/19/hmg2010.pdf

Ullah, W. (2017). Evolving corporate governance and firm's performance: Evidence from Japanese firms. Economics of Governance, 18(1), 1-33.

Waheed, A., \& Malik, Q. A. (2019). Board characteristics, ownership concentration and firms' performance. South Asian Journal of Business Studies, 8(2), 146165.

Wang, K., \& Shailer, G. (2015). Ownership concentration and firm performance in emerging markets: A meta analysis. Journal of Economic Surveys, 29(2), 199-229.

Wang, X., Cao, J., Liu, Q., Tang, J., \& Tian, G. G. (2015). Disproportionate ownership structure and IPO long-run performance of non-SOEs in China. China Economic Review, 32, 27-42.

Yasser, Q. R., \& Mamun, A. A. (2017). The impact of ownership concentration on firm performance: Evidence from an emerging market. Emerging Economy Studies, 3(1), 34-53. 